\title{
PERANCANGAN SISTEM INFORMASI REGISTRASI MAHASISWA
}

\author{
Helpi Nopriandi \\ Fakultas Teknik, Universitas Islam Kuantan Singingi, Teluk Kuantan \\ email : helpinopriandi83@gmail.com
}

\begin{abstract}
Abstrak
Penerapan sistem informasi yang tepat di perguruan tinggi dapat menjadi kekuatan bersaing (competitive advantage) bagi perguruan tinggi untuk dapat exist. Hampir dapat dipastikan saat ini, perguruan tinggi yang tidak mempunyai sentuhan teknologi informasi secara perlahan namun pasti akan ditinggalkan oleh calon mahasiswa. Dalam penelitian ini metode-metode dalam penelitian laporan yaitu pengumpulan data dan observasi langsung pada pengolahan sistem informasi registrasi mahasiswa serta wawancara dengan bagian administrasi yang masih manual dalam mengolah data mahasiswa. Maka dari itu dibuatlah suatu sistem informasi yang baru dengan menggunakan Program Visual Basic, ini bertujuan untuk mengatasi masalah pengolahan sistem informasi registrasi mahasiswa pada Sekolah Tinggi khususnya dibagian administrasi, untuk memperoleh suatu keuntungan dalam memberikan informasi yang cepat dan tepat dalam pengolahan data mahasiswa.
\end{abstract}

Kata Kunci : Sistem Informasi, Registrasi, Visual Basic

\begin{abstract}
Implementation of appropriate information systems in universities can be a competitive power (competitive advantage) for universities to exist. Almost certainly this time, colleges that do not have a touch of information technology slowly but surely will be abandoned by prospective students. In this research methods in research reports that is data collection and direct observation on the processing of student registration information system as well as interviews with the administration that is still manual in processing student data. Therefore created a new information system using Visual Basic Program, This aims to address the problem of processing student registration information system at High School especially in the administration section, to obtain an advantage in providing information quickly and precisely in processing student data.
\end{abstract}

Keyword : Information System, Registration, Visual Basic 


\section{PENDAHULUAN}

Dalam Era Globalisasi saat ini, ilmu pengetahuan mempunyai peranan penting dalam menentukan kemajuan dan keberhasilan bagi suatu Negara, perkembangan ilmu pengetahuan khususnya dalam bidang teknologi dimanfaatkan untuk meningkatkan pembangunan dan kemampuan Nasional serta mempercepat terjadinya proses pembaharuan menuju terciptanya masyarakat yang maju dan sejahtera. Seperti kita lihat teknologi informasi telah dimanfaatkan disegala bidang kehidupan manusia, mulai dari Pendidikan, Teknik Industri, Jasa, Perkantoran, Kesehatan, Transfortasi, Perbankan dan bidang-bidang lainnya.

Pemanfaatan Teknologi Informasi dan Komunikasi pada bidang layanan administrasi akademik di perguruan tinggi menjadi suatu kebutuhan, bukan hanya sekedar prestise atau lifestyle manajemen pendidikan tinggi modern [1]. Penggunaan teknologi informasi memang menawarkan banyak keuntungan, yaitu dalam pengelolaan data maupun dalam menghasilkan informasi yang efektif, efisien, cepat dan akurat. Dengan adanya teknologi informasi banyak pekerjaan mudah dalam melaksanakannya.

Pada Sekolah Tinggi Teknologi memang sudah menggunakan sistem aplikasi sederhana tetapi belum menggunakan aplikasi pemograman. Untuk menangani Sistem registrasi Mahasiswa, sistem yang ada masih memerlukan perbaikan karena dibagian ini sering mengalami kesulitan dalam mengolah data. Selanjutnya dengan memperhatikan hal-hal tersebut diatas, penelitian ini mencoba untuk memperoleh data empirik yang cukup lengkap dan dapat dipercaya untuk menggambarkan tentang keadaan faktor-faktor yang terkait dengan pengelolaan Sistem Informasi berbasis Teknologi Informasi terhadap kinerja perguruan tinggi dan dampaknya terhadap prestasi akademik mahasiswa. Data yang telah diperoleh juga dapat digunakan untuk mengembangkan alternatif model Sistem Informasi Manajemen Akademik yang dapat memberi dukungan pada setiap proses pelayanan akademik maupun pengambilan keputusan baik di lingkungan internal maupun yang terkait dengan stakeholders.

Sistem Informasi Registrasi dihimpun dari berbagai macam data yang dikelola dan diproses se-otomatis mungkin dengan alat dan metoda sehingga menghasilkan informasi yang diperlukan bagi terlaksananya kegiatan akademis.

Berdasarkan uraian permasalahan di atas, maka penelitian yang dilaksanakan ini mempunyai beberapa tujuan antara lain :

1. Untuk mengaplikasikan suatu sistem informasi registrasi mahasiswa (Kartu Hasil Studi dan Kartu Rencana Studi) dengan memanfaatkan Teknologi Informasi secara cepat, tepat dan akurat.

2. Untuk membantu staff tenaga kependidikan dalam pengolahan Kartu Hasil Studi dan Kartu Rencana Studi.

3. Untuk menambah wawasan penulis dalam menganalisa, merancang dan mengolah data mahasiswa dalam bentuk Kartu Hasil Studi dan Kartu Rencana Studi. 


\section{TINJAUAN PUSTAKA}

\subsection{Konsep Dasar Sistem Informasi}

Sistem adalah jaringan dari pada element-element yang saling berhubungan yang membentuk satu kesatuan untuk melaksanakan suatu tujuan pokok dari sistem tersebut. Untuk mengetahui sistem atau bukan, antara lain dapat dilihat dari ciri-cirinya . ada beberapa rumusan mengenai sistem ciri-ciri sistem ini yang pada dasarnya satu sama lain saling melengkapi. Pada umumnya ciri-ciri sistem ini adalah : bertujuan, punya batas, terbuka, tersusun dari sub sistem, ada yang saling berkaitan dan tergantung merupakan kebulatan yang sistematik.

Sistem informasi terdiri dari beberapa komponen. Dalam buku "Prinsip-Prinsip Sistem Informasi Manajemen", pengertian sistem informasi adalah sistem informasi yang diciptakan oleh para pengolahan data anak, data kegiatan, data sponsor, data pemeriksaan kesehatan, pemeriksaan sosio emosi, data perpindahan anak, data pejabat, data tutor, bantuan pelayanan dan data inventarisasi barang analisis dan manajer guna melaksanakan tugas khusus tertentu yang sangat esensial bagi berfungsinya organisasi [2].

Menurut Indrayani [3] pemanfaatan teknologi informasi dan komunikasi pada bidang layanan administrasi akademik di perguruan tinggi menjadi suatu kebutuhan, bukan hanya sekedar prestige atau lifestyle manajemen pendidikan tinggi modern. Kemudian Sistem informasi adalah suatu sistem di dalam suatu organisasi yang mempertemukan kebutuhan pengolahan transaksi harian, mendukung operasi, bersifat manajerial dan kegiatan strategi dari suatu organisasi dan menyediakan pihak luar tertentu dengan laporan-laporan yang diperlukan [4].

Rancangan sistem Informasi adalah merancang atau membuat sistem baru yang diterapkan untuk mengatasi masalah yang lama. Perancangan sistem dapat diartikan sebagai tahap setelah analisis dari sirklus pengembangan sistem, pendefinisian dari kebutuhankebutuhan fungsionalis, persiapan untuk rancangan bangunan implementasi, menggambarkan bagaimana suatu sistem dibentuk (penggambaran, perencanaan, pembatasan sketsa) termasuk mengkonfigurasi komponen-komponen perangkat lunak dan perangkat keras dari suatu sistem [5].

\subsection{Konsep Dasar Database}

Database merupakan sistem file komputer yang menggunakan cara pengorganisasian file tertentu, dimaksudkan untuk pembaharuan masing-masing record terkait juga mempermudah dan mempercepat akses data tersimpan, yang harus digunakan secara bersama-sama untuk dibaca guna menyusun laporan-laporan rutin, laporan-laporan atau khusus untuk penyelidikan. Database juga merupakan sekumpulan file-file atau tabel-tabel yang saling berhubugan dan salaing berinteraksi untuk menghasilkan informasi yang berguna bagi pemakai. 


\section{METODE PENELITIAN}

Dalam penelitian ini diawali dengan menganalisa kebutuhan sistem, mempertimbangkan setiap kriteria yang akan digunakan dalam perancangan sistem adapun metode penelitian dengan carai menggunakan metode deskriptif analitik yang berjenis survey, turun langsung ke lapangan mengadakan observasi tentang hal-hal yang berkaitan dengan masalah yang dibahas, pengumpulan konsep teori dengan mempelajari literatur dan buku yang ada hubungannya dengan permasalahan dan penelitian laboratorium yaitu usaha penulis dalam mengolah informasi yang diperoleh.

\section{HASIL DAN PEMBAHASAN}

Setelah melakukan tahap implementasi sistem maka dapat diketahui bahwa hasil dari penelitian ini adalah terciptanya program aplikasi sistem Informasi Registrasi Mahasiswa yang dibuat dengan menggunakan bahasa pemrogramman microsoft visual basic 6.0.

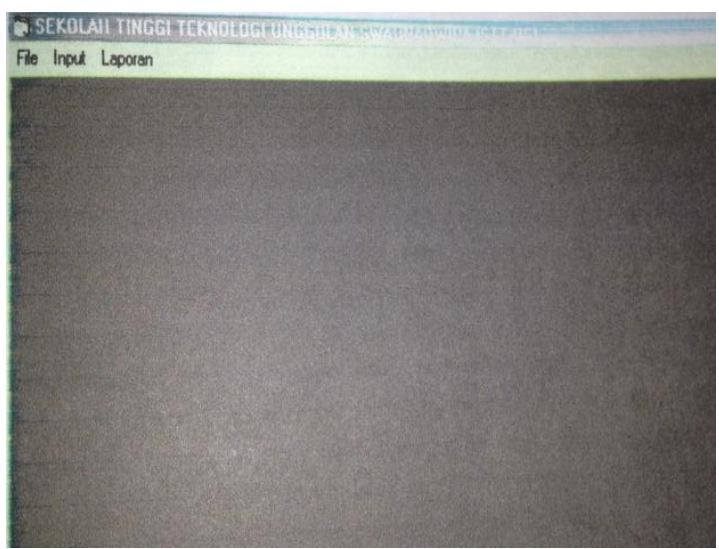

(a) Form Menu Utama

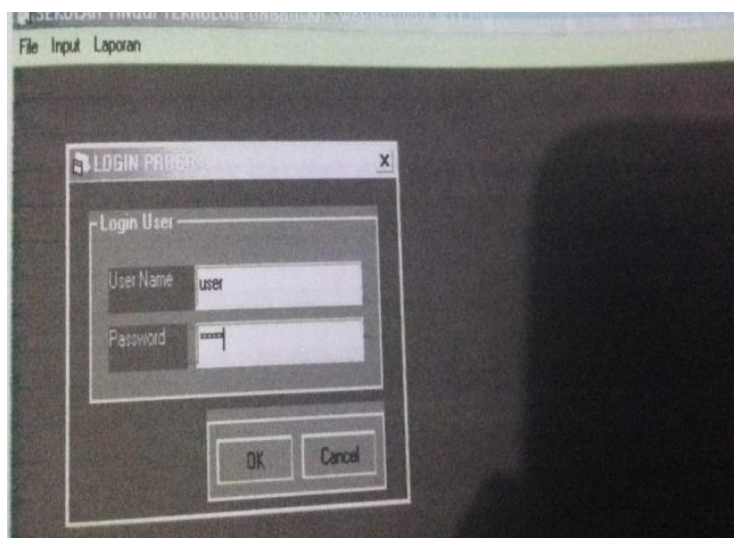

(b) Form Menu Login

Gambar (a) Form menu utama adalah form yang akan pertama kali tampil pada program Sistem Informasi Registrasi Mahasiswa. Pada menu ini terdapat 3 (tiga) menu yaitu file input fan laporan. Gambar (b) menunjukan form login digunakan untuk membuka aplikasi apabila kita ingin menjalankan program.

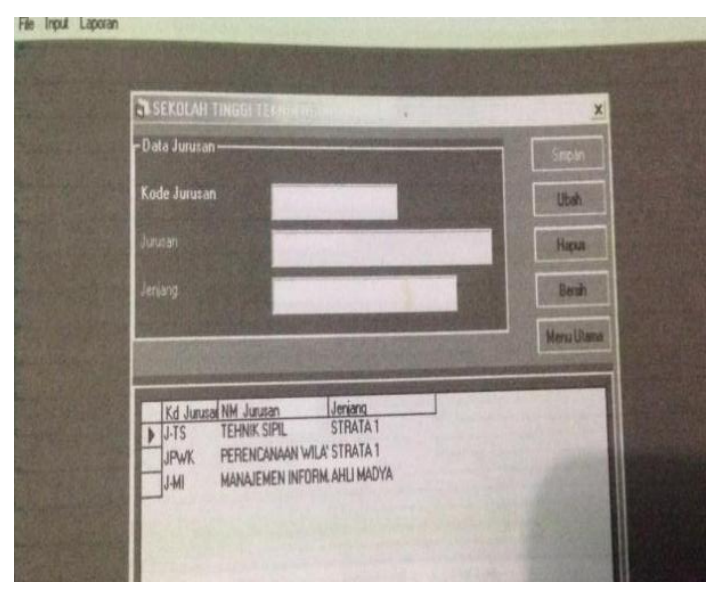

(c) Form Jurusan

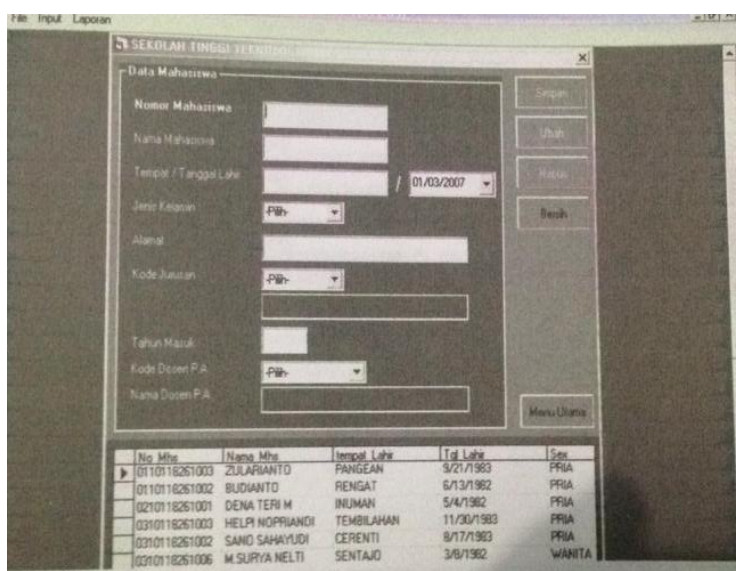

(d) Form Data Mahasiswa 
Pada dasarnya setiap perguruan tinggi memiliki Jurusan atau Program Studi, gambar (c) berguna untuk memasukkan data-data jurusan yang berguna pada saat pengisian data Mahasiswa. Apabila form jurusan tidak diisi maka data mahasiswa tidak akan sempurna karna form satu dengan form lainnya sangat berhubungan. Pada form ini terdapat 3 (tiga) item yaitu kode jurusan, nama jurusan dan jenjang. Sedangkan gambar (d) adalah form Data Mahasiswa, form ini digunakan untuk memasukkan data mahasiswa yang terdiri dari Nama Mahasiswa, Tempat tanggal lahir, jenis kelamin, alamat, jurusan tahun masuk dan penasehat akademis.

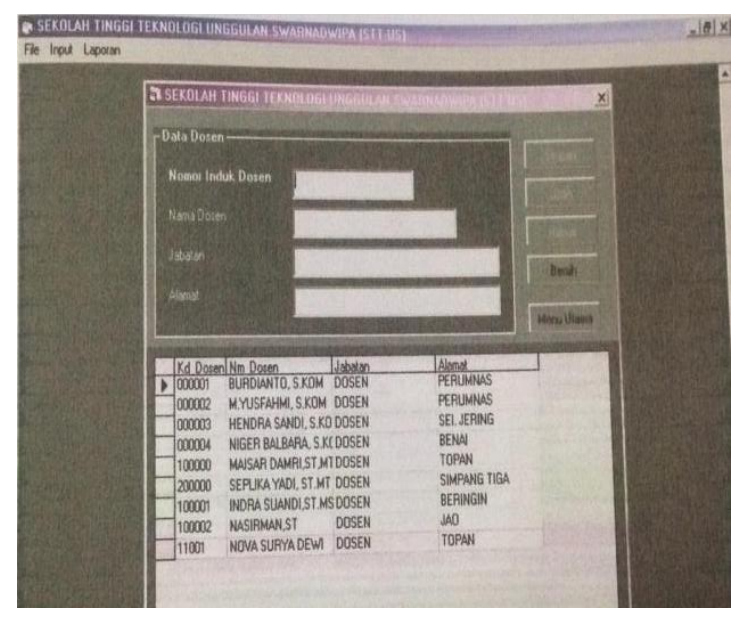

(e) Form Dosen

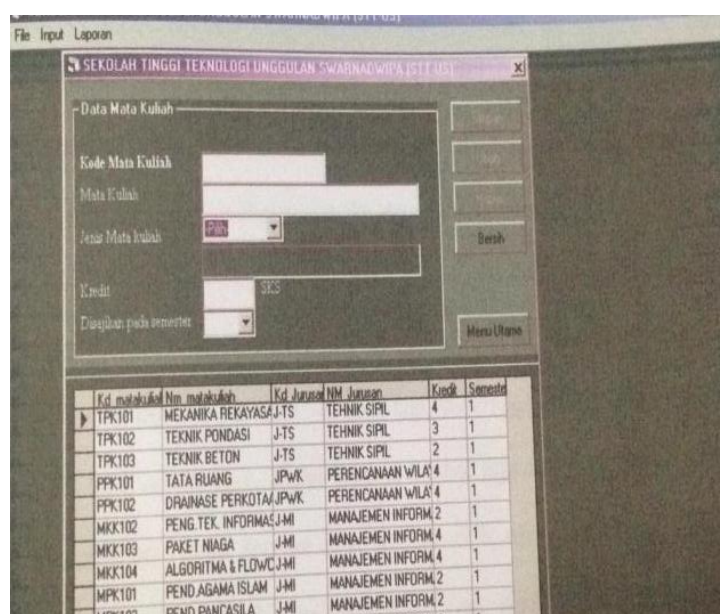

(f) Form Mata Kuliah

Gambar (e) merupakan Form Dosen, form ini berguna untuk memasukkan data-data Dosen yang terdiri dari Nomor Induk Dosen, Nama Dosen, Jabatan dan alamat. Gambar (f) adalah Form Mata Kuliah data-data form ini nantinya akan tampil dalam form KRS dan KHS. Data form mata kuliah merupakan data pertama sekali yang diperlukan untuk pembuatan laporan KRS dan KHS.

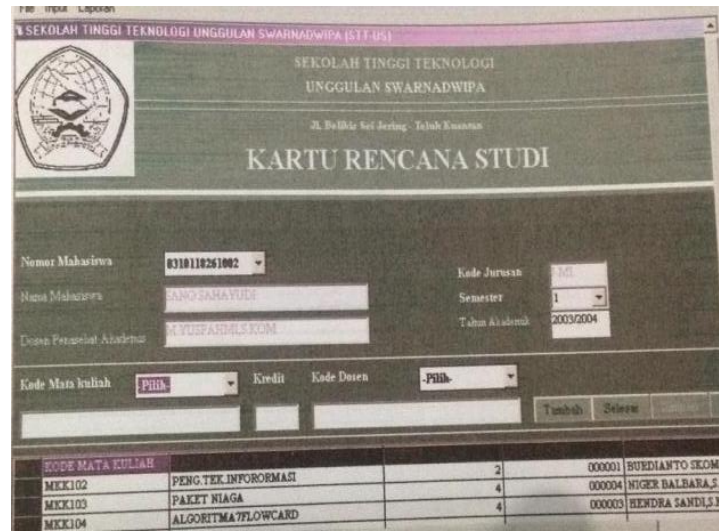

(g) Form Kartu Rencana Studi

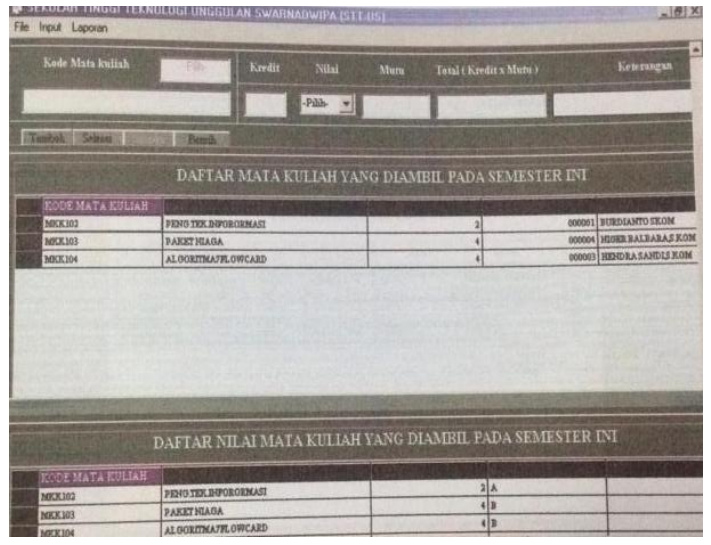

(h) Form Kartu Hasil Studi

Form kartu rencana studi (g) berguna untuk membuat laporan kartu rencana studi, dimana laporan ini merupakan gabungan dari semua form-form yang sudah dibuat kecuali 
form hasil studi karna form kartu studi didapat setelah form kartu rencana diisi. Dalam menjalankan form ini cukup mengisi nomor mahaiswa dan mengisi mata kuliah apa saja yang akan diambil. Sedangan gambar (h) adalah form kartu hasil studi disini kita hanya memasukkan nilai mahasiswa berdasarkan berita acara nilai.

Setelah semua form diisi maka selanjutnya akan menampilkan beberapa laporan yaitu :

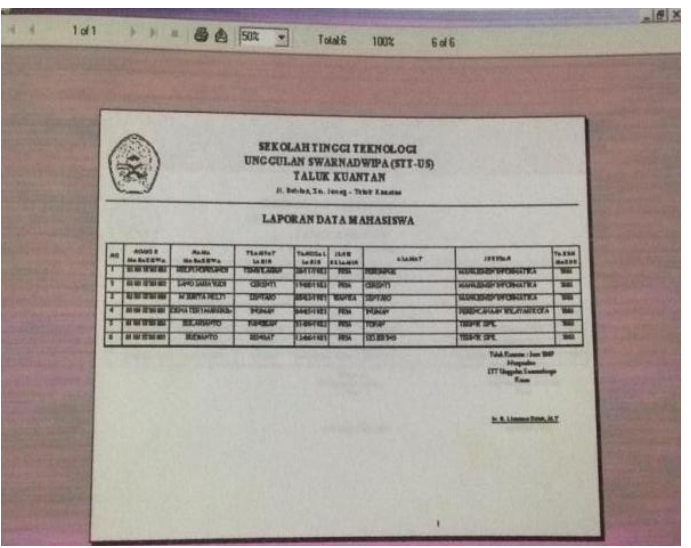

(i) Laporan Mahasiswa Keseluruhan

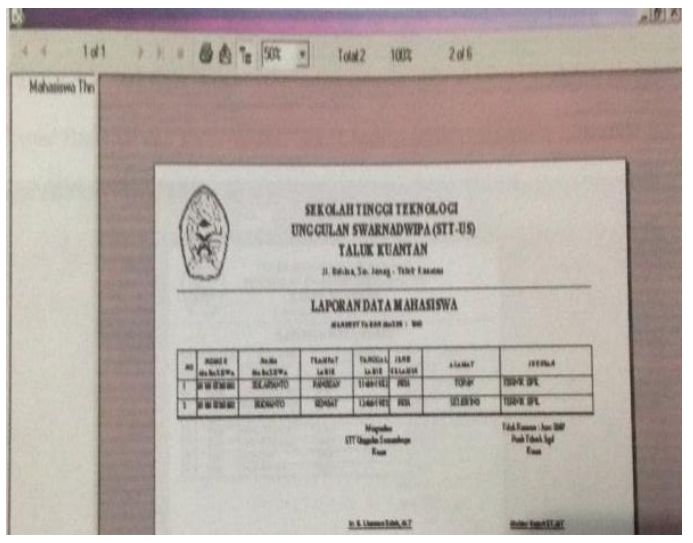

(k) Laporan Mahasiswa per Tahun Masuk

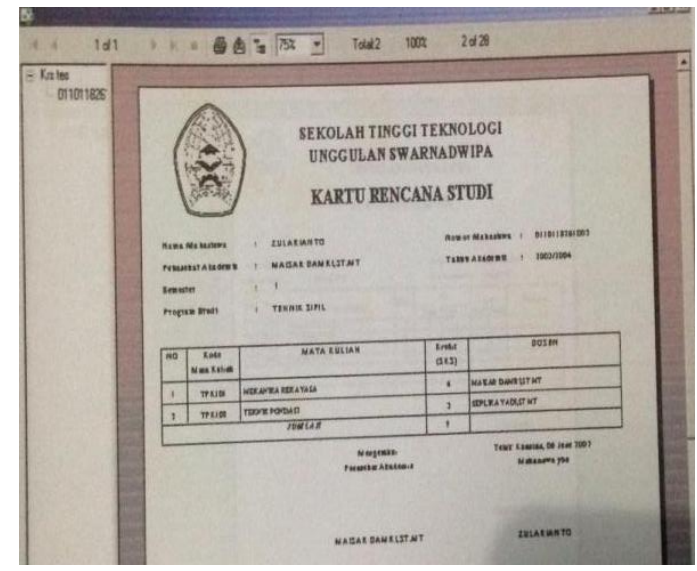

(m) Laporan Kartu Rencana Studi

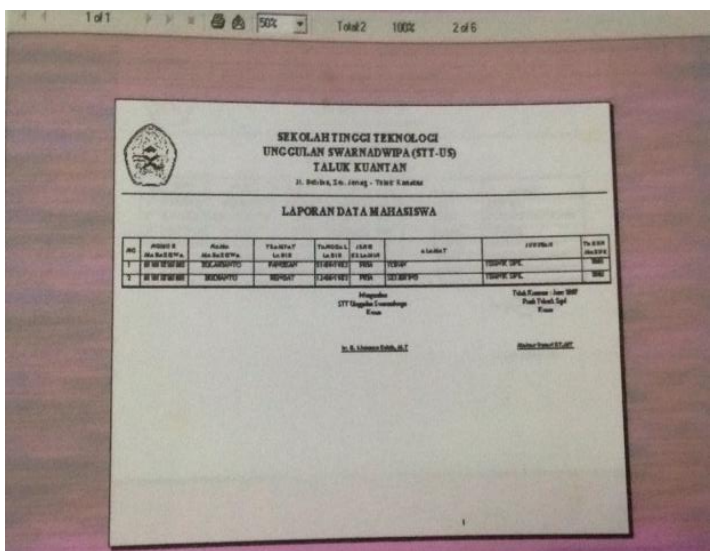

(j) Laporan Mahasiswa per program studi

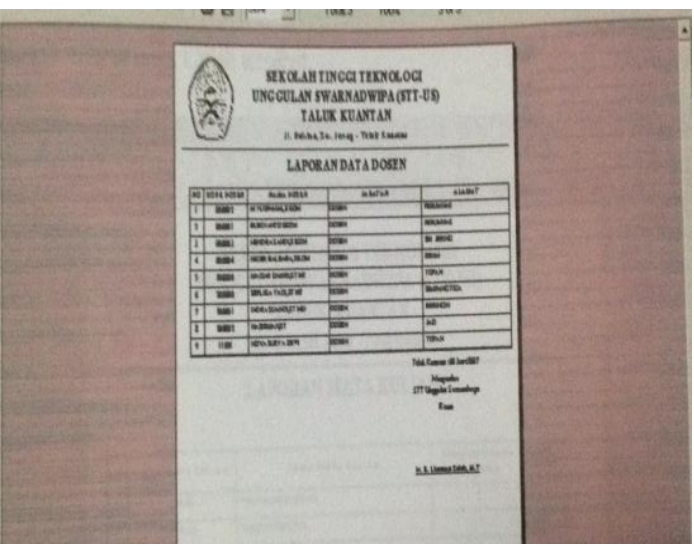

(1) Laporan Dosen

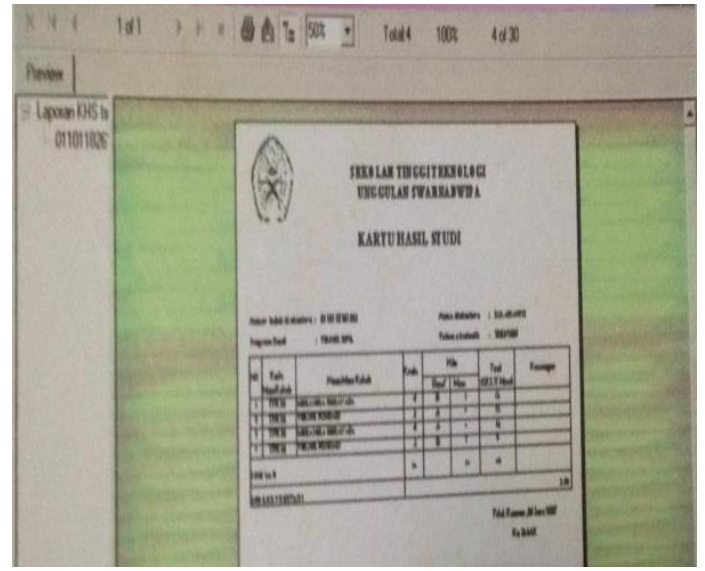

(n) Laporan Hasil Studi 


\section{SIMPULAN}

Pada bagian ini penulis mengambil kesimpulan dari hasil penelitian yaitu : (a). Dengan perancangan sistem informasi registrasi mahasiswan yang menerapkan database dan menggunakan bahasa pemograman Visual Basic 6.0, maka pelayanan terhadap mahasiswa seperti penambahan, penghapusan, koreksi atau penyisipan danpembuatan laporan registrasi baik yang sudah ada maupun data yang baru akan dapat diatasi dalam waktu yang relatif cepat karena semua data tersimpan dalam sebuah database. (b). Dengan mengembangkan sistem pengolahan data yang berbasis komputer serta variabel-variabel yang mendukung untuk pembentukan atau pembuatan laporan tersebut tersusun secara logis yang tidak dilakukan secara berulang-ulang. (c). Dengan diterapkannya sistem ini untuk mengurangi pemakaian sumberdaya manusia (meminimumkan tenaga kerja) dengan tidak mengurangi mutu pelayanan. Disini juga penulis memberikan saran diantaranya (a). Dengan menggunakan sistem ini diharapkan kepada pihak Sekolah Tinggi agar dapat mengatasi kendala-kendala yang ada dari segi biaya dan waktu yang digunakan. (b) Supaya mutu pelayanan dapat ditingkatkan lagi sehingga akan mahasiswa merasa puas.

\section{UCAPAN TERIMA KASIH}

Penulis mengucapkan terima kasih kepada semua pihak yang telah membantu penulis dalam penelitian ini. Kedua Orang Tua, Ketua Sekolah Tinggi, Pembimbing, Pegawai dan rekan-rekan yang terlibat.

\section{DAFTAR PUSTAKA}

[1] Etin Indrayeni (2011).” Pengelolaan Sistem Informasi Akademik Perguruan Tinggi Berbasis Teknologi Informasi Dan Komunikasi (TIK) "Jurnal Penelitian Pendidikan Vol. 12, No. 1

[2] Regina, L, Adriana, F dan Sebastianus, Adi, S (2014)." Implementasi Sistem Informasi Pengolahan Data Anak Berbasis Desktop Pada Pusat Pengembangan Anak Io-625 Efata Liliba". J-ICON ISSN : 2337-7631Vol. 2 No. 2, Oktober 2014

[3] Muh. Rasyir, R, Usman dan Dwi, Y,P (2015)," Desain dan Implementasi Sistem Informasi Akademik". Jurnal Buana Informatika, Volume 6, Nomor 2, April 2015.

[4] Tedi, K, Dini, D dan Asep, D,S (2012).” Perancangan Sistem Informasi Akademik Nilai Siswa Berbasis Web" Jurnal Algoritma ISSN : 2302-7339 Vol. 09 No. 17

[5] Rahmat Hidayat (2009)." Penerapan Sistem Informasi Manajemen Sebagai Alat Pelaksanaan Sistem Administrasi Akademik”. Jurnal Ilmiah Pendidikan Tinggi Volume 2, Nomor 2, ISSN: 1979-9640 